\title{
Application of time series control charts to model and monitor the seasonality of norovirus
}

Aplicação de gráficos de controle de séries temporais para modelagem e monitoramento da sazonalidade do norovírus

Aplicación de gráficas de control de series temporales para modelado y monitoreo de la estacionalidad del norovirus

Jones Anderson Monteiro Siqueira

Núcleo de Medicina Tropical, Universidade Federal do Pará, Belém, Pará, Brasil

Anna Alice Garcia Caldas Nunes

Departamento de Estatística, Universidade Federal de Viçosa, Viçosa, Minas Gerais, Brasil

Milene Silveira Ferreira

Núcleo de Medicina Tropical, Universidade Federal do Pará, Belém, Pará, Brasil

\author{
Alexandre da Costa Linhares \\ Seção de Virologia, Instituto Evandro Chagas/SVS/MS, Ananindeva, \\ Pará, Brasil \\ Edson Marcos Leal Soares Ramos \\ Instituto de Ciências Exatas e Naturais, Universidade Federal do Pará, \\ Belém, Pará, Brasil \\ Yvone Benchimol Gabbay \\ Seção de Virologia, Instituto Evandro Chagas/SVS/MS, Ananindeua, \\ Pará, Brasil
}

\begin{abstract}
INTRODUCTION: Time series control charts are tools that allow one to identify the nature of certain variations in a process, whether they are variations due to common causes, deemed of little importance, or to special causes. The goal of this study was to apply time series control charts to analyse the seasonality observed in norovirus infections in children admitted from May 2008 to April 2011 to a paediatric hospital in Belém City, Pará State, Amazon Region, Brazil. MATERIALS AND METHODS: To apply the models, it was necessary to make the stationary series, which was performed by applying the first difference of monthly norovirus positivity rates. To construct the charts, KolmogorovSmirnov normality test was used to verify if the data were normally distributed. RESULTS: During the three years, the highest prevalence was observed between September and October 2008 (63.6\%) and February 2010 (62.1\%). The study series was under statistical control, with a tendency for stability and no evidence of seasonality or cycle. No outlying values were observed, which strongly suggest that no atypical factor that could affect the stability of the series was present. CONCLUSION: This study demonstrates the applicability of time series control charts in the seasonality analysis of several pathogens studied in the biomedical sciences, and it is the first time that this statistical method has been applied to assess the time distribution of norovirus.
\end{abstract}

Keywords: Time Series; Seasonal Variation; Norovirus; Gastroenteritis.

\section{INTRODUCTION}

Exploratory or descriptive data analysis involves gathering, characterising and presenting a set of data to properly describe the characteristics of this set'. There are many descriptive tools in statistics, such as plots, tables and synthesis measurements (percentages, indexes, averages, medians, etc. $)^{2}$.

\footnotetext{
Correspondence / Correspondência / Correspondencia:

Yvone Benchimol Gabbay

Instituto Evandro Chagas, Seção de Virologia

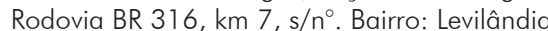

CEP: 67030-000 Ananindeua-Pará-Brasil

Phone \#: +55 (91) 3214-2015 / 3214-2006

E-mail: yvonegabbay@iec.pa.gov.br
}

Time series is the class of phenomena in which data are distributed in an ordered sequence of observations, i.e., the set of observations is obtained sequentially with time. If the parameter $t$ represents time, the series itself can be a function of some other physical parameter, such as space or volume. The series can be observed as a $r \times 1$ vector, where $t$ is a $p \times 1$ vector. These series serve the following purposes: (1) to identify the behaviour of the series, as confirming the existence of tendencies, cycles and seasonal variations, outliers, etc.; (2) to use the variations in one series to explain those observed in another series; and (3) to make predictions of future values of the time series based on a mathematical model that describes the behaviour observed ${ }^{3}$.

Control charts are very useful to determine if the variations observed in a process are due to common causes, deemed to have little importance, or to special causes, which must be identified and eliminated from 
the process ${ }^{4}$. Thus, the control plot is a graphical representation of the process with time. The control plot consists of a central line $(\mathrm{CL})$, that represents the distribution level, and two other lines that represent the upper and lower control limits (UCL and $L C L)^{5}$ (Figure 1). These control limits are used to assess whether the process is under statistical control, which is true if the sampled data points lie between the two limits. However, if a data point lies outside the control limits, or when there are a sequence of points (seven or more consecutive data points), then the process is out of statistical control, which requires investigation into the attributable causes for this behaviour ${ }^{6}$.

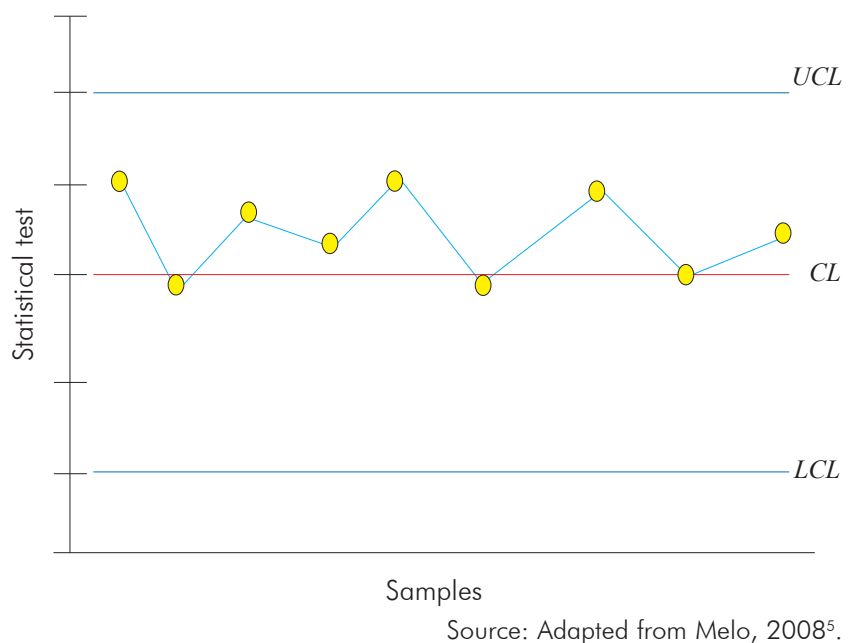

Figure 1 - Shewhart-type control chart model

Control charts are based on certain premises, including a sampling statistic $w$, which continuously measures the variability of a quality trait, providing the mean and standard deviation. These statistical values correspond to the points in the control chart, and each point is obtained from one of the samples gathered from the process in well-defined time frames. Formally, the general model of control charts is defined as follows:

$$
\begin{gathered}
U C L=\mu_{w}+k \sigma_{w} \\
C L=\mu_{w} \\
L C L=\mu_{w}+k \sigma_{w}
\end{gathered}
$$

where $k$ is the distance between the central line and each of the control limits, given as a function of the standard deviation ${ }^{7}$.

Certain assumptions must be made before creating a control chart, such as independence and normality of the data. If these assumptions are true, the charts are applicable, and conclusions about a given process can be drawn. Therefore, it is essential for the variability control of a process that the quality trait be not only normally distributed but also independently and identically distributed, which implies that the variables are not autocorrelated ${ }^{8}$.
Norovirus (NoV) is belonging to the Caliciviridae family, which includes four other genera: Sapovirus (SaV), Lagovirus, Vesivirus and Nebovirus. Along with $\mathrm{SaV}, \mathrm{NoV}$ is called human caliciviruses, and NoV is the most prevalent genera in the world. This virus is morphologically characterised as non-enveloped viruses, measuring between 27 and $40 \mathrm{~nm}$ in diameter, with a non-smooth external surface and non-pronounced spikes. The viral capsid has icosahedral symmetry, consisting of one single structural protein that forms 32 depressions in the shape of chalices ${ }^{9}$.

Among all viral enteropathogens, NoV is the most important when considering outbreaks in human populations. This virus is the second major cause of severe viral acute gastroenteritis (AGE) in young children in the world, is responsible for $20 \%$ of family outbreaks and is the main cause of diarrhoea in travellers. This virus is particularly infectious in children and elderly people but they can infect individuals from all age groups. In addition to causing severe infections, NoV causes large economic losses, with annual supply and human resources expenditures of approximately US\$ 650,000, not including hospitalisation costs, according to a study conducted in the USA ${ }^{10}$.

This virus is responsible for approximately $90 \%$ of all non-bacterial diarrhoea outbreaks and for $12 \%$ of $A G E$, which cause approximately 200,000 deaths of children under 5 years old, especially in developing countries. In the United States, studies conducted starting in 1972 estimate that $94 \%$ of the non-bacterial outbreaks and 38.6 million (80\%) of the annual cases of AGE can be attributed to these agents ${ }^{11}$.

In Brazil, studies involving the epidemiological and molecular aspects of those viruses have already been conducted. The prevalence of NoV has been investigated in a longitudinal study conducted in urban shanty towns in Fortaleza, Ceará State, between 1990 and 1991, involving 120 children, with a positivity of $12.5 \%$. This pathogen was also detected in $15 \%$ of the children hospitalised in Recife, Pernambuco State, between 2004 and $2005^{12}$.

In 1996, the first outbreak caused by these viruses in Brazil occurred in Baixada Santista, São Paulo State ${ }^{13}$, and many outbreaks in the capital city of the same State were recorded in 1995 and from 2004 to 2006 with a positivity of $15.7 \%^{14}$.

NoV has also been associated with several AGE outbreaks in Rio de Janeiro, both in the capital of that State $(37.6 \%)$ and other municipalities $(66 \%)^{15,16}$, and has been observed in $14.5 \%$ of all clinical samples acquired from children who were hospitalised or received outpatient treatment in Rio de Janeiro. In the central-western region of the country, $8.6 \%$ positivity was observed among hospitalised children ${ }^{17}$, whereas in Espírito Santo State, the figure was $39.7 \%^{18}$. 
In Pará State, tests conducted on faecal samples acquired from children admitted to a public hospital in the Capital Belém between 1992 and 1994 identified $\mathrm{NoV}$ in $15 \%$ of the samples ${ }^{19}$. According to other studies performed from 1998 to 2000, 2003 and from 2008 to 2010 the positivity rates for hospitalised children in the same city varied between $7.1 \%$ and $36.5 \% 20,21,22$.

The high infectiousness of this pathogen suggests a large variety of transmission routes. The main route is the faecal-oral one (person-to-person contact, fomites, vomit aerosolisation and consumption of contaminated food and water). The ease with which these viruses are transmitted and the low infecting dosage required to establish an infection result in the already mentioned extensive outbreaks, particularly in contained environments such as hospitals, hotels, schools, cruise ships, prisons, child care centres, restaurants and nursing homes. The main clinical manifestations characterising the infection are diarrhoea, vomit, nausea and abdominal pain lasting for approximately $48 h^{23,24}$.

Thus, the present study aimed to apply control charts of time series to the analysis of the seasonality observed in the NoV detected in children suffering from AGE in a paediatric hospital in Belém City, Pará State, Amazon region, Brazil, over a period of three years of monitoring.

\section{MATERIALS AND METHODS}

\section{SAMPLE COLLECTION}

Active surveillance was performed in a paediatric hospital for three years (May 2008 to April 2011). Children admitted with the symptoms of AGE, characterised by three or more episodes of liquid or loose diarrhoea in a period of $24 \mathrm{~h}$, were observed. All sick children were initially tested for a rotavirus infection, and only those that tested negative were included in the present study. The selection of which children would be tested for a NoV infection was performed monthly in a random manner, using a ballot to minimise selection biases, and included approximately $20 \%$ of the children in the hospital.

A total of 10.030 cases of hospitalizations was registered during the three years of follow-up, with 2.276 faecal samples collected and included in this study, of which 483 were selected to be tested for the presence of $\mathrm{NoV}$, adopting a confidence level of $95 \%$ and a sampling error of $4 \%$.

The use of the samples obtained in this clinic was authorised by the Committee for Ethics in Research in Humans of the Instituto Evandro Chagas, under register CAAE: 0024.0.072.000-10 dated October 15 th 2010.

\section{LABORATORY PROCEDURES}

Faecal suspensions were prepared either in an elution buffer of enzymatic assay or in Tris $/ \mathrm{HCl} / \mathrm{Ca}^{++}$ $0.01 \mathrm{M} \mathrm{pH} 7.2$ at a concentration of 10\% weight/ volume.
All the samples were examined for the presence of $\mathrm{NoV}$ antigens using the commercial $3^{\text {rd }}$ generation immunoenzymatic assay (IEA) Ridascreen ${ }^{\circledR}$ Norovirus (R-Biopharm, Darmstadt, Germany), according to the manufacturer's instructions. This IEA is based on monoclonal antibodies observed attached on the surface of the wells of the microplate, which capture antigens specific to NoV (Gl and GII) observed in faecal samples. Regardless of the results, all the samples were also tested using molecular biology techniques.

Total nucleic acid extraction was performed using the silica method (Guanidine isothiocyanate) ${ }^{25}$. Complementary DNA (cDNA) was acquired using reverse transcription reaction with a random primer (pd [N] 6-50A 260 units - Amersham Biosciences, Piscataway, NJ) and reverse transcriptase enzyme (Superscript TM II RNAse H Reverse, Invitrogen, Eugene, Oregon, USA).

The genetic material was amplified via a polymerase chain reaction (PCR) using two primers, Mon 432/434 and Mon 431/433, which in the viral genome code is the $3^{\prime}$ end of the $B$ region of ORF 1 (RNA-dependent polymerase). These primers are specific to detect the Gl and Gll genogroups of NoV, forming a nucleotide fragment with $213 \mathrm{bp}^{26}$.

Positive and negative controls were included at all the stages of these procedures, from the extraction of viral RNA to the PCR, to control and guarantee the quality of the results.

\section{CONSTRUCTION OF THE CONTROL CHART OF THE TIME SERIES}

The construction of this chart considers how well it detects points that are out of statistical control, if any such points exist. Monitoring the original values facilitates understanding and analysis of the data ${ }^{27}$, i.e., the central line allows seasonality traits of the series to be considered and the monitoring to be more effective. Thus, the limits of the control chart and the central line were given by the following:

$$
\begin{gathered}
U C L=\hat{y}_{t}+k M A D \\
C L=\hat{y}_{t} \\
L C L=\hat{y}_{t}+k M A D
\end{gathered}
$$

where $k$ is the distance from the central line to each of the control limits, given as a function of the standard deviation, $\hat{y}_{t}$ is the $t$-th estimate obtained from the time series model (in this case $k=3$ was used), and MAD is the mean absolute error computed as follows:

$$
M A D=\sum_{t=1}^{n} \frac{\left|y_{t}-\hat{y}_{t}\right|}{n}
$$

\section{SOFTWARE}

The statistical analyses were conducted using Gretl 1.9.5, Minitab 14 and BioEstat 5.028 computer programmes. The charts in this article were produced using Microsoft Office Excel 2007. 


\section{RESULTS}

NoV-positivity of $35.4 \%$ (171/483) was detected in the period of surveillance, not being observed any cases of obit due to AGE. Three positivity peaks (cut-off 60\%) were observed between May 2008 and April 2011, in September and October 2008 (63.6\%) and February 2010 (62.1\%) (Figure 2).

To apply the models proposed in this study, it was necessary to make the series stationary, which was accomplished by applying the first difference of monthly NoV positivity rates. One single application sufficed to make the series stationary (Figure 3).

Two models, MA(1) and $A R(4)$, were assessed for series monitoring and predictions. Table 1 presents the MAD and the Akaike criterion for the monthly NoV positivity rate series, as observed in children hospitalised with AGE during the period of study. The MA(1) time series model was used, which was fitted to this data series as follows:

$$
y_{t}=29,37+a_{t}-0,660799 a_{t-1}
$$

Control charts of time series were used to monitor the monthly positivity percentages as functions of time during the three years of observation. To construct these charts, it was crucial to verify whether the data were normally distributed, that was determined using the Kolmogorov-Smirnov normality test, in which the following hypotheses were tested: $\mathrm{H}_{0}$ : the data are normally distributed; $H_{1}$ : the data are not normally distributed. The test results indicated that the data were normally distributed, yielding a p-value of 0.941 at a $5 \%$ significance level.

To monitor the series, the establishment of upper and lower control limits was also necessary; these limits were given by the following equations:

$$
\begin{gathered}
U C L=\hat{y}_{t}+3 \times 13,876 \\
C L=\hat{y}_{t}=29,37+a_{t}-0,660799 a_{t-1} \\
L C L=\hat{y}_{t}+3 \times 13,876
\end{gathered}
$$

Thus, the time series control chart was constructed for the data from the monthly NoV positive case distribution as detected in the period of observation of this study (Figure 4).

Table $1-M A D$ and Akaike criterion for the series and monthly norovirus positivity rates observed in children hospitalised due to gastroenteritis during the three years of observation (May 2008 to April 2011) in a paediatric hospital in Belém, Brazil

\begin{tabular}{ccc}
\hline Model & MAD & Akaike criterion \\
\hline MA(1) & 13.876 & 302.567 \\
AR(4) & 15.224 & 306.307 \\
\hline
\end{tabular}

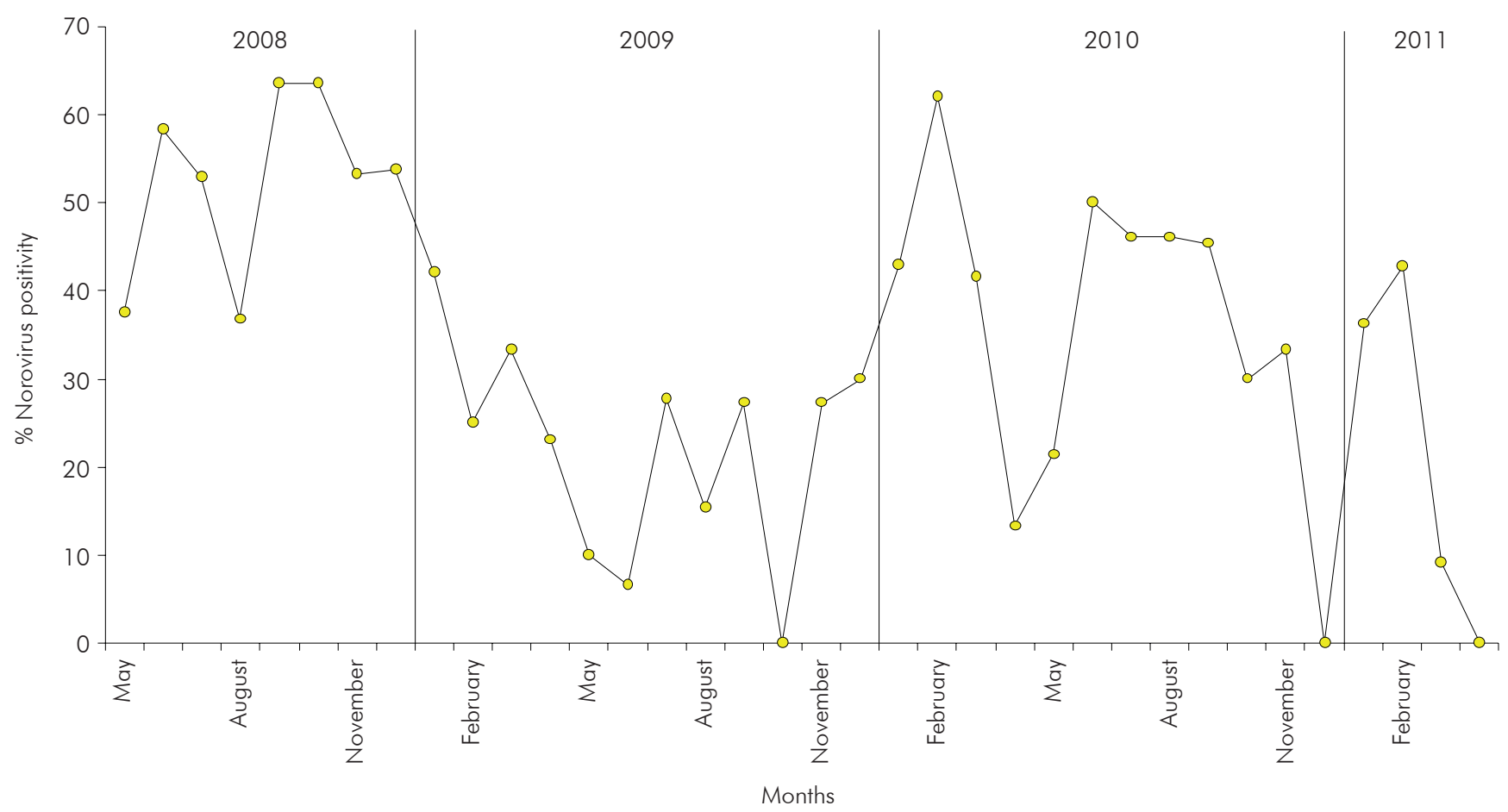

Figure 2 - Monthly distribution of positive norovirus cases detected in children hospitalised due to gastroenteritis during the three years of observation (May 2008 to April 2011) in a paediatric hospital in Belém, Pará, Brazil 


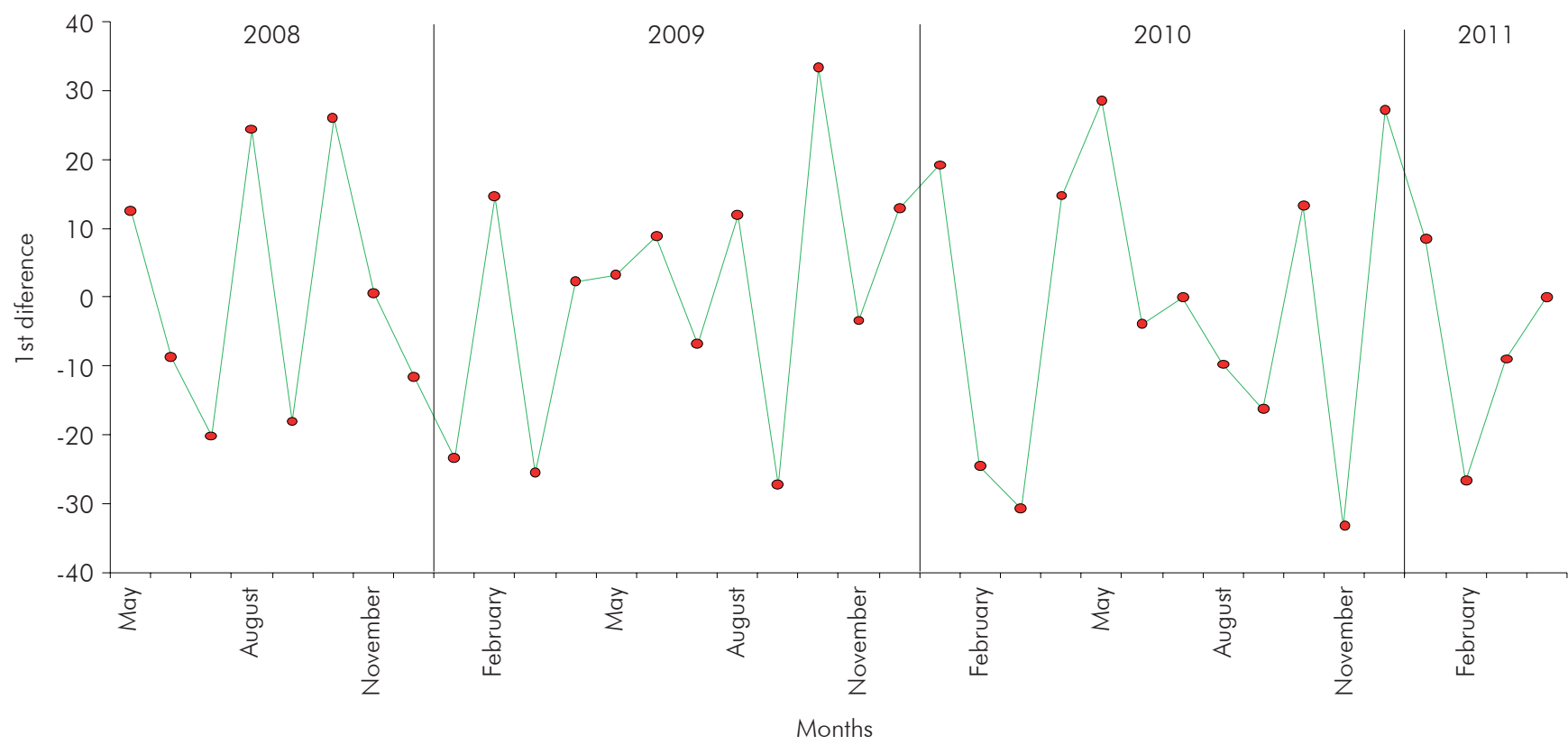

Figure 3 - First difference in monthly norovirus positivity rates detected in children hospitalised due to gastroenteritis during the three years of observation (May 2008 to April 2011) in a paediatric hospital in Belém, Pará, Brazil

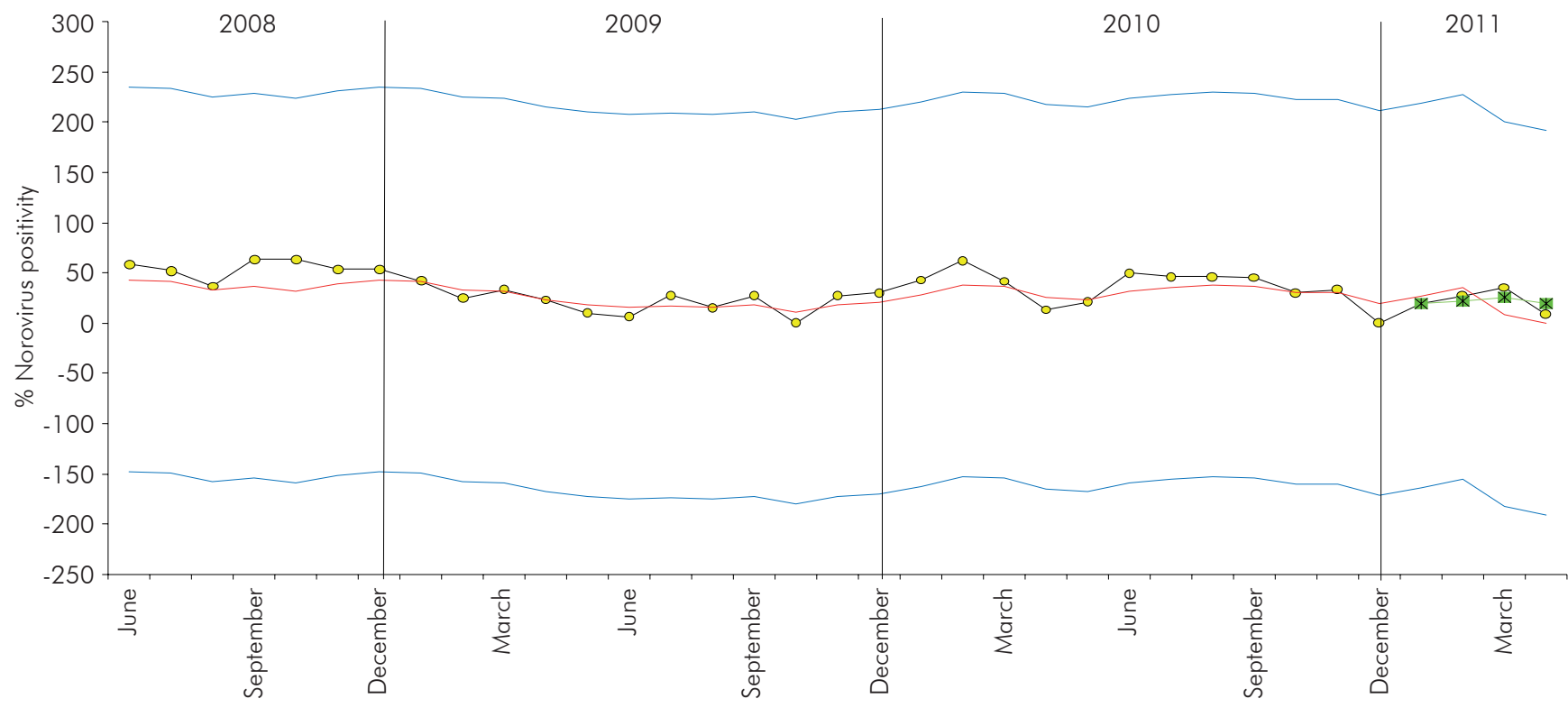

Months

Figure 4 - Time series control chart for the monthly positivity percentage observed for norovirus between May 2008 and April 2011 in Belém, Pará, Brazil

\section{DISCUSSION}

Seasonality studies indicate an increase in NoV infection rates in winter months in countries of temperate climate $^{29}$. This behaviour was also observed in a study conducted over a period of eight years (1998-2007) in the Southeastern Region of Brazil. However, in tropical regions such as the North of Brazil, infections caused by these pathogens are observed all year long, with some months of greater occurrence, but without establishing a seasonality pattern ${ }^{30}$.

NoV also circulate in the central region of the country (subtropical climate), with their prevalence peaking from September to March, which corresponds to the rainy season and higher humidity ${ }^{17}$. However, another study conducted in Rio de Janeiro observed a two-phase prevalence profile with peaks in the periods of March to May and of September to October of $2004^{31}$. This latter peak is similar to the one observed in the present study. In fact, similar to these other regions, Belém did not display a seasonal NoV infection pattern.

These data indicate that further study is necessary to better clarify which factors affect the viral infection rates and whether climate or population behavioural factors are involved, especially considering that Brazil has continental dimensions and that the Amazon Region, the location where the study was conducted, is likely to significantly differ from other regions of the country and the entire world in epidemiological terms. Despite this, the idea of applying mathematical modelling to the 
results seems to be very beneficial to confirm, statistically, the findings. Furthermore, these analyses can be valuable to understand more complex interrelationships between numerous variables and shock factors.

Studies in which mathematical modelling is used are being conducted in the fields of biological and medical sciences to guide actions in public health ${ }^{32}$, assess infection control measures ${ }^{33}$ and examine therapeutic treatments ${ }^{34}$. In the context of time series, there are several criteria to select mathematical models for monitoring and predictive series, with the most commonly used being the Akaike information criterion (AIC), for which a lower value for AIC implies a better adjusted model ${ }^{35}$. Note that the value of $M A D$ was lower for the $M A(1)$ model than for the $A R(4)$ model, and thus, the former has a lower AIC value, suggesting that MA(1) is a better model for estimating the series.

The time series control chart demonstrated that the series studied is under statistical control, with a tendency for stability, no evidence of seasonality (an indication of a fluctuation pattern with a yearly period) nor of cycle (an indication of patterns in the series that repeat at intervals larger than a year). No outlying values were observed during the three years, which strongly suggests that no atypical factor that could affect the stability of the series or biases in the monthly sample collection were present. Although, it has already been proven that exist other statistical methods it can be applied to assess the seasonality of pathogens, none is so accurate and allows many analyzes as the presented tool to this study.

\section{CONCLUSION}

The goal of this study was to model and monitor the monthly NoV positivity rates observed over a period of three years in children hospitalised due to AGE.

The NoV detected in these hospitalised children during this three-year period in Belém did not display any well-defined seasonality, in contrast with what is usually observed in countries in the Northern Hemisphere, which could be attributed to climate factors or behaviour traits of the population under study.

The mathematical model for time series analysis also suggests that the selection and sample collection were performed well, without the occurrence of outbreaks of the disease caused by NoV in the paediatric population under study. However, it should be noted that this type of seasonality assessment was conducted under an essentially non-representative premise about the true distribution of NoV infections because only children who tested negative for rotavirus were included in the study. This practice could potentially represent a significant bias but does not invalidate the present study.

Finally, this study demonstrated the applicability of time series control charts in the biomedical sciences as a useful tool for the seasonality analysis of several pathogens and is the first study to apply this kind of statistical analysis having norovirus as object of study.

\section{ACKNOWLEDGEMENTS}

The authors would like to thank the Statistical and Computational Study and Research Group (GEPEC) and the Information and Georeferencing Systems Laboratory (LASIG) at the Universidade Federal do Pará for their continuous teaching. The authors would also like to thank the Norovirus and others Enteric Virus Laboratory of the Instituto Evandro Chagas for all the technical and logistic support, particularly regarding the laboratory processing of the samples. Special thanks are due to those responsible for the children hospitalised in the Pará Paediatric Clinic, informally known as Clínica Serzedelo Corrêa, who accepted to participate in this study as volunteers and permitted the analysis of the relevant biological material. The authors are also thankful to the entire team of the Effectiveness Project, which conducted the on-site sample and data collection.

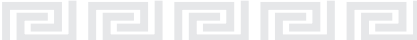

\section{Aplicação de gráficos de controle de séries temporais para modelagem e monitoramento da sazonalidade do norovírus}

\section{RESUMO}

INTRODUÇÃO: Os gráficos de controle de séries temporais são ferramentas que permitem identificar a natureza de certas variações em um processo, sejam elas variações devido a causas comuns, consideradas de pouca importância, ou a causas especiais. O objetivo deste estudo foi aplicar gráficos de controle de séries temporais para analisar a sazonalidade observada em infecções de norovírus, em crianças internadas no período de maio de 2008 a abril de 201 1, em um hospital pediátrico na Cidade de Belém, Estado do Pará, Amazônia, Brasil. MATERIAIS E MÉTODOS: Para aplicar os modelos, foi necessário fazer a série estacionária, realizada pela aplicação das primeiras diferenças de taxas de positividade do norovírus. Para construir os gráficos, foi utilizado o teste de normalidade de Kolmogorov-Smirnov, a fim de verificar se os dados foram distribuídos corretamente. RESULTADOS: Durante os três anos, observou-se a maior prevalência entre setembro e outubro de 2008 (63,6\%) e fevereiro de 2010 (62,1\%). A série de estudo estava sob controle estatístico, com uma tendência para a estabilidade e nenhuma evidência de sazonalidade. Não foram observados valores periféricos que sugerem claramente que nenhum fator atípico pode prejudicar a estabilidade da série apresentada. CONCLUSÃO: Este estudo demonstra a aplicabilidade de gráficos de controle de séries temporais na análise da sazonalidade de diversos patógenos estudados nas ciências biomédicas, sendo a primeira vez que este método estatístico foi aplicado para avaliar a distribuição temporal de norovírus.

Palavras-chave: Séries Temporais; Variação Sazonal; Norovirus; Gastroenterite. 


\section{Aplicación de gráficas de control de series temporales para modelado y monitoreo de la estacionalidad del norovirus}

\section{RESUMEN}

INTRODUCCIÓN: Las gráficas de control de series temporales son herramientas que permiten identificar la naturaleza de ciertas variaciones en un proceso, sean variaciones debido a causas comunes, consideradas de poca importancia, o a causas especiales. El objetivo de este estudio fue de aplicar gráficas de control de series temporales para analizar la estacionalidad observada en infecciones de norovirus, en niños internados en el período de mayo de 2008 a abril de 2011, en un hospital pediátrico en la Ciudad de Belém, Estado de Pará, Amazonía, Brasil. MATERIALES Y MÉTODOS: Para aplicar los modelos, fue preciso hacer la serie estacionaria, realizada por aplicación de las primeras diferencias de tasas de positividad del norovirus. Para construir las gráficas, se utilizó la prueba de normalidad de Kolmogorov-Smirnov, con la finalidad de verificar si los datos habían sido distribuidos correctamente. RESULTADOS: Durante los tres años, se observó una mayor prevalencia entre setiembre y octubre de 2008 (63,6\%) y febrero de 2010 (62,1\%). La serie de estudio estaba bajo control estadístico, con una tendencia a la estabilidad y ninguna evidencia de estacionalidad. No se observaron valores periféricos que sugieran claramente que ningún factor atípico puede perjudicar la estabilidad de la serie presentada. CONCLUSIÓN: Este estudio demuestra la aplicabilidad de gráficas de control de series temporales en el análisis de la estacionalidad de diversos patógenos estudiados en las ciencias biomédicas, siendo la primera vez que este método estadístico fue aplicado para evaluar la distribución temporal de norovirus.

Palabras clave: Series Temporales; Variación Estacional; Norovirus; Gastroenteritis.

\section{REFERENCES}

1 Levine DM, Berenson ML, Stephan D. Basic business statistics: concepts and applications. New Jersey: Prentice Hall; 1996.

2 Bussab OW, Morettin PA. Estatística básica. São Paulo: Saraiva; 2011.

3 Morettin PA, Toloi CMC. Análise de séries temporais. São Paulo: Edgar Blucher; 2004.

4 Ramos EMLS, Almeida SS, Araújo AR. Controle estatístico da qualidade. Porto Alegre: Bookman; 2013.

5 Melo GM. Decomposição da estatística teste do gráfico de controle multivariado $\mathrm{T}^{2}$ de Hotelling para monitoramento e avaliação do controle de processos de agências bancárias [dissertação]. Belém (PA): Universidade Federal do Pará; 2008.

6 Nunes AAGC. Modelagem e monitoramento dos casos notificados de hanseníase no estado do Pará [monografia]. Belém (PA): Universidade Federal do Pará; 2011.

7 Shewhart WA. Economic control of quality of manufactured product. Princeton: Van Nostrand Reinhold; 1931.

8 Montgomery DC. Introdução ao controle estatístico da qualidade. Rio de Janeiro: LTC; 2004.

9 International Committee on Taxonomy of Viruses. Virus taxonomy: classification and nomenclature of viruses - Ninth Report of the International Committee on Taxonomy of Viruses. London: Elsevier; 2012. Chapter, Part II - The Viruses: Family Caliciviridae; p. 977-86.
10 Lindesmith LC, Donaldson EF, LoBue AD, Cannon JL, Zheng D-P, Vinje J, et al. Mechanisms of Gll.4 norovirus persistence in human populations. PLoS Med. 2008 Feb;5(2):e31.

11 Patel MM, Widdowson MA, Glass Rl, Akazawa K, Vinjé $J$, Parashar UD, et al. Systematic literature review of role of noroviruses in sporadic gastroenteritis. Emerg Infect Dis. 2008 Aug; 1 4(8): 1224-31.

12 Nakagomi T, Correia JB, Nakagomi O, Montenegro FM, Cuevas LE, Cunliffe NA, et al. Norovirus infection among children with acute gastroenteritis in Recife, Brazil: disease severity is comparable to rotavirus gastroenteritis. Arch Virol. 2008 May; 153(5):957-60.

13 Ueda M, Kisielius JJ, Timenetsky MCST, Carmona RCC, Tanaka H. Small round structured virus SRVS, genogroup G2 in Baixada Santista (SP): virus identification BT Immune Electron Microscopy (IEM). In: I Simpósio de Segurança Alimentar e Saúde do Estado de São Paulo; 1998 set 21-23; São Paulo: CIP; 1998.

14 Morillo SG, Cilli A, Carmona RCC, Timenetsky MCST. Identification and molecular characterization of norovirus in São Paulo State, Brazil. Braz J Microbiol. 2008 Dec;39(4):619-22.

15 Gallimore Cl, Barreiros MA, Brown DW, Nascimento JP, Leite JP. Noroviruses associated with acute gastroenteritis in a children's day care facility in Rio de Janeiro, Brazil. Braz J Med Biol Res. 2004 Mar;37(3):321-6.

16 Ferreira MS, Xavier MP, Fumian TM, Victoria $M$, Oliveira SA, Pena LH, et al. Acute gastroenteritis cases associated with norovirus infection in the state of Rio de Janeiro. J Med Virol. 2008 Feb;80(2):338-44. 
17 Borges AM, Teixeira JM, Costa PS, Giugliano LG, Fiaccadori FS, Franco RC, et al. Detection of calicivirus from fecal samples from children with acute gastroenteritis in the West Central Region of Brazil. Mem Inst Oswaldo Cruz. 2006 Nov; $101(7): 721-4$.

18 Ribeiro LR, Giuberti RSO, Barreira DMPG, Saick KW, Leite JPG, Miagostovich MP, et al. Hospitalization due to norovirus and genotypes of rotavirus in pediatric patients, State of Espirito Santo. Mem Inst Oswaldo Cruz. 2008 Mar; 103(2):201-6.

19 Nakamura LS, Oliveira DS, Silva PF, Lucena MS, Mascarenhas JD, Gusmão RH, et al. Molecular characterization of calicivirus in feces of children with acute diarrhea, attending a public hospital, in Belém, Pará. In: XVII National Meeting of Virology; 2006 19-22; Campos do Jordão: Sociedade Brasileira de Virologia; 2006. p. 95. (Virus Reviews \& Research; vol. 11 ; supl. 1).

20 Siqueira JAM, Nascimento IS, Oliveira DS, Soares LS, Aragão GC, Mendes YG. Caracterização molecular de calicivírus humano em amostras fecais de crianças atendidas em um posto de saúde de Belém, Pará entre os anos de 1998 e 2000. In: 62 ${ }^{a}$ Reunião Anual da Sociedade Brasileira para o Progresso da Ciência; 2010 jul 25-30; Natal: Sociedade Brasileira para o Progresso da Ciência; 2010.

21 Aragão GC, Oliveira DS, Santos MC, Mascarenhas JDP, Oliveira CS, Linhares AC, et al. Molecular characterization of norovirus, sapovirus and astrovirus in children with acute gastroenteritis from Belém, Pará, Brazil. Rev Pan-Amaz Saude. 2010 mar; 1 (1):149-57.

22 Siqueira JAM, Linhares AC, Carvalho TCN, Aragão GC, Oliveira DS, Santos MC, et al. Norovirus infection in children admitted to hospital for acute gastroenteritis in Belém, Pará, Northern Brazil. J Med Virol. 2013 Apr;85(4):737-44.

23 Bull RA, Tu ETV, Mclver CJ, Rawlinson WD, White PA. Emergence of a new norovirus genotype II.4 variant associated with global outbreaks of gastroenteritis. J Clin Microbiol. 2006 Feb;44(2):327-33.

24 Tu ETV, Bull RA, Greening GE, Hewitt J, Lyon MJ, Marshall JA, et al. Epidemics of gastroenteritis during 2006 were associated with the spread of norovirus Gll.4 variants 2006a and 2006b. Clin Infect Dis. 2008 Feb;46(3):413-20.

25 Boom R, Sol CJ, Salimans MM, Jansen CL, Wertheim-van Dillen PM, van der Noordaa J. Rapid and simple method for purification of nucleic acids. J Clin Microbiol. 1990 Mar;28(3):495-503.
26 Anderson AD, Garrett VD, Sobel J, Monroe SS, Fankhauser RL, Schwab KJ, et al. Multistate outbreak of norwalk-like virus gastroenteritis associated with a common caterer. Am J Epidemiol. 2001 Dec;154(11):1013-9.

27 Moreira Junior FJ. Proposta de um método para o controle estatístico de processo para observações autocorrelacionadas [dissertação]. Porto Alegre (RS): Universidade Federal do Rio Grande do Sul; 2005.

28 Ayres M, Ayres Jr M, Ayres DL, Santos AS. BioEstat 5.0: aplicações estatísticas nas áreas das ciências biológicas e médicas. Belém: Instituto de Desenvolvimento Sustentável Mamirauá; 2007.

29 Fretz R, Herrmann L, Christen A, Svoboda P, Dubuis $\mathrm{O}$, Viollier $\mathrm{EH}$, et al. Frequency of Norovirus in stool samples from patients with gastrointestinal symptoms in Switzerland. Eur J Clin Microbiol Infect Dis. 2005 Mar;24(3):214-6.

30 Soares CC, Santos N, Beard RS, Albuquerque MC, Maranhão AG, Rocha LN, et al. Norovirus detection and genotyping for children with gastroenteritis, Brazil. Emerg Infect Dis. 2007 Aug;13(8):1244-6.

31 Victoria M, Carvalho-Costa FA, Heinemann MB, Leite JP, Miagostovich M. Prevalence and molecular epidemiology of noroviruses in hospitalized children with acute gastroenteritis in Rio de Janeiro, Brazil, 2004. Pediatr Infect Dis J. 2007 Jul;26(7):602-6.

32 Milne GJ, Baskaran P, Halder N, Karl S, Kelso J. Pandemic influenza in Papua New Guinea: a modelling study comparison with pandemic spread in a developed country. BMJ Open. 2013 Mar;3:e002518.

33 Hughes H, Britton NF. Modelling the use of Wolbachia to control dengue fever transmission. Bull Math Biol. 2013 May;75(5):796-818.

34 Miller JK, Brantner JS, Clemons C, Kreider KL, Milsted A, Wilber $\mathrm{P}$, et al. Mathematical modelling of Pseudomonas aeruginosa biofilm growth and treatment in the cystic fibrosis lung. Math Med Biol. 2014 Jun;31 (2): 179-204.

35 Muradás Neto MV, Carvalho PLC, Sáfadi T. Análise preditiva e comparativa para séries de combustíveis no município de Lavras. In: 53 Reunião Anual da Região Brasileira da Sociedade Internacional de Biometria. 2008 mai 14-6; Lavras: Universidade Federal de Lavras; 2008.

Received / Recebido em / Recibido en: 29/8/2014 Accepted / Aceito em / Aceito en: 2/4/2015 